\title{
Perspective parents toward students diversity in inclusive education elementary school
}

\author{
Mumpuniarti Mumpuniarti ${ }^{1}$, C. Asri Budiningsih ${ }^{1}$, Dinar Westri Andini ${ }^{2 *}$, Ayu Rahayu ${ }^{2}$ \\ ${ }^{1}$ Universitas Negeri Yogyakarta. Jalan Colombo No. 1, Yogyakarta 55281, Indonesia \\ ${ }^{2}$ Universitas Sarjanawiyata Tamansiswa. Jalan Batikan UH-III/1043 Yogyakarta 55167, Indonesia \\ * Corresponding Author. E-mail: dinar@ustjogja.ac.id \\ Received: 1 September 2019; Revised: 20 September 2019; Accepted: 14 November 2019
}

\begin{abstract}
The perspective of parents who support student diversity in school will open to a variety of different problems. The attitude is expected to encourage the implementation of integration and harmony among diversity. Therefore, the objective of the study was to describe the views of parents towards student diversity in inclusive education. Diversity from the perspective of parents determines the attitude of agreeing and disagree, as well as the right view of inclusive. The research method used a questionnaire to respondents of 99 parents from elementary schools in five regencies of the Special Region of Yogyakarta (DIY). The results showed that the majority of parents still had a narrow understanding that the concept of inclusive was the same with Student Educational Need (SEN). Here, the concept of labelling might understand as a misconception phenomenon. However, the majority of parents agreed to the SEN in regular schools, but an understanding of separate learning is the responsibility of the special supervisor or, interpreted as the inclusion officer. The implications need the education to understand the inclusion correctly and discuss the perspectives of parents to contribute to the success of learning in inclusive elementary schools.
\end{abstract}

Keywords: perspective parent, student diversity; inclusive education

How to Cite: Mumpuniarti, M., Budiningsih, C., Andini, D., \& Rahayu, A. (2019). Perspective parents toward students diversity in inclusive education elementary school. Jurnal Prima Edukasia, 7(2), 139-149. doi:https://doi.org/10.21831/jpe.v7i2.26937

do:

https://doi.org/10.21831/jpe.v7i2.26937

\section{Introduction}

Inclusive education has been implemented comprehensively in the Province of Special Region of Yogyakarta with supported by Governor Policy. Also, in other regions of Indonesia, even not all regions have the policy to support inclusive education. The statement of inclusive education in Indonesia which open for anyone is an agreement from many countries, including Indonesia. This statement supports the equality of right among the gender, race, and different backgrounds, such as economic social status and ability ("The Salamanca Statement and Framework for Action on Special Needs Education.," 2014).

The paradigm should be entrenched and become a policy for education administrators, especially in primary schools. The school that assumes as a miniature of society should build the attitudes of tolerance, respect the differences, and mutual help among individuals. The attituded and characters need in daily due to become the image of society in dealing with differences. Inclusive education is not something that must be started, but it must always continue to develop. The ongoing and developing inclusive education needs the attention of all sectors, dimensions, and stakeholders in education. The consideration of all sectors, dimensions, and stakeholders determines the success and sustainability of inclusive education because all parties support and contribute to the implementation of inclusive education.

The practice of learning in the concept of inclusive education must engage all the diversity of students, including diversity of ability to follow the learning in the classroom (Parsons \& Taylor, 2011). The movement of inclusive education aims to provide equal education for all request all the parties to join. Parents, education administrators, education politic experts, public administrators for education, and the theory of education must work together in inclusive education movement (Salend \& Garrick Duhaney, 
Jurnal Prima Edukasia, 7 (2), 2019 - 140

Mumpuniarti Mumpuniarti, C. Asri Budiningsih, Dinar Westri Andini, Ayu Rahayu

1999). One of the dimensions is the involvement of parents. Because, the parent is a supporting factor of the success of learning for students who are studying at inclusive schools (Christenson, 2003; Hill \& Taylor, 2004). Parents with open views toward inclusive education at school will have an impact on attitude to support and join in the implementation and give feedback on the improvement of the school in providing an experience of best service for students (Paseka, Schwab, \& Paseka, 2019).

The role of parents is crucial. The parents will support the learning outcome and their children toward multi-approach learning in diversity in the school. They also have a role for students' achievement, based on their perspective. Their perspective of inclusive education affect the attitude and behave, which manifest into learning support for various concepts of learning (Burstein, Sears, Wilcoxen, Cabello, \& Spagna, 2004; Walker, Hoover-Dempsey, Whetsel, \& Green, 2004; Wertheim \& Leyser, 2002). This point becomes a highlight regarding the importance of support from the parent that in inclusive class, the diversity of students, such as ability will learn together in a class. Therefore, curriculum adaptation is needed to reach the success of learning with the aim all the students reach the maximum achievement based on their respective abilities (UNESCO, 1994).

Adaptation of the curriculum as a consequence to accommodate the student diversity, and views of justice, as well as equality. Student diversity is natural and must give attention to administrate inclusive learning. The implication of student diversity is an effort to adapt the curriculum to accommodate the learning needs of each student (Foreman, 2014; Kauffman \& Hallahan, 2011; Parker \& Villalpando, 2007). The implementation of the curriculum adaptation needs to be assessed from the parents' view toward student diversity.

The views of parents determine expectations of diversity achievement because children who are students in inclusive primary schools have diverse potential and traits. Parents expect their children's learning achievement following individual conditions. Also, parents consider that schools provide varied learning treatments, which affect the different results of learning achievement. Parents are aware that their children are excel in certain fields, but not in other fields. Parents also consider that learning accommodation through curriculum adaptation is a natural consequence of student diversity.
The implications of parents' views on the diversity of students in inclusive primary schools need to be actualized because of the cultural dimension, the policy dimension, and the dimensions of learning implementation. They must know that to accommodate the diversity of students required the characteristics of dimensions that contain inclusive values. The value of equality, fairness, diversity, collaboration, accepting the special needs of each student at a very significant or insignificant level, is a colour in the implementation of inclusive education. Parents who already have a view of these values will also play a role in guiding their children collaboratively in the framework of curriculum adaptation (Wertheim \& Leyser, 2002). It will provide information and mutual communication between teachers and parents. Parents will provide information and feedback, specifically about the situation and learning needs of the students for the curriculum adaptation. Parent, who was engaging in developing of learning strategy following the need of students based on perspective, they will not only develop a strategy to meet the need of students but also encouraging collaboration between their children and fellow students. The problem of learning will solve through seeking the solution by respecting the right of other students, by applying normalization, adjustment of age, unlimited area, and all children learning the concepts collaboratively. The solution depends on parents' perspective on diversity (Hebel \& Persitz, 2014; Hughes \& Kwok, 2007; LaRocque, Kleiman, \& Darling, 2011; Wang, Haertel, \& Walberg, 1993).

Diversity of students is available in the movement of inclusive education (Foreman, 2014; Hallahan \& Kauffman, 2003; Kauffman \& Hallahan, 2011). The diversity of students must be accommodated well because every student needs a learning environment according to their needs (Conderman, Liberty, \& DeSpain, 2017; Kauffman \& Hallahan, 2011). Accommodation refers to the act of modification and adaptation of the curriculum to adapt to students learning needs through an assessment process. After that, learning goals, learning material, and methods must also be through the adaptation process. Various learning need easily solve on collaboration with parents. And, parents can encourage their children to reach the learning goal in line with students learning needs. Parent will receive adequate understanding on reaching the learning goal on diversity of students after they agreed to collaborate in curriculum implementation (Bakar, 
2018; Burstein et al., 2004; Foreman, 2014; Goddard, Tschannen-Moran, \& Hoy, 2001; Komsi, Hambali, \& Ramli, 2018; Walker et al., 2004).

The success of curriculum adaptation that carefully considers and follows the student's need will well implement when parents strongly agreed on every dimension of inclusive education implementation. The response of agreeing to means to support and be ready to collaborate with the school to follow up on the learning outcome of their children. Also, it involves facilitating all the teachers' efforts to encourage education inclusively. Therefore, their perspective must be through some assessment of views toward the values of inclusive learning in the school. The result will use as the insights on curriculum adaptation that involve parents. If the views of parents disagree with a response or need information about inclusion, then, it will become the recommendation for school to educate parents. Parents who disagree with the view of inclusion will become a burden to the school (Kantavong, Sujarwanto, Rerkjaree, \& Budiyanto, 2017; Kavale \& Forness, 2000). It sometimes affects on accepting and views of their children toward diversity in the school.

Previous research, on the perspectives of the parent toward the learners, examined the aspects of parent involvement to improve academic achievement (Hill \& Taylor, 2004; HooverDempsey et al., 2001; Walker et al., 2004). Another research found out that parent has a higher positive response and accepting on SEN students who have physical and sensorimotor disabilities, such as learning disabilities of students who have problems of emotional, act and intellectual (Paseka et al., 2019). The research assumed that children with problems of emotional, act and intellectual would become a constraint in the learning process in the class. Based on these studies, it needs to conduct further research on the perspective of parents on student diversity. Because diversity needs to be interpreted as the nature of students. The meaning determines the attitude of acceptance of various problems and the implications of the various problems by seeking the alternative or accommodation of various difficulties that occur in students. Therefore, the purpose of this study was to describe the perspective of parents on student diversity as the implications of ongoing inclusive education. A correct parent perspective on inclusive education uses as the basis to support inclusive education implementation through positive view and pro- viding the opportunity to all children, including SEN to collaborate in the learning process and help for increasing the accommodations towards student diversity. The parent will support the determined learning program and adaptation of differences standard to provide justice and equality based on students' potency. Moreover, parents will strongly support the process of understanding every child to the diversity of students in the school. Here, parents explain the values of respect, so that accepting the diversity will be well implemented. However, if the parents' perspective on inclusive education is not correct for the improvement of the concept of inclusion, it will become an obstacle to the success of the implementation of inclusive education in schools. And, through education to parents will build a correct understanding.

\section{Method}

The research method was a survey with questionnaire instruments. The questionnaire was developed and compiled by the parent's perspective toward student diversity. The components were parents' understanding of the concept of inclusive education, accepting the SEN students in regular schools; attitude towards labelling of SEN, opinions of SEN must be in special schools; views of SEN unable to follow the regular school curriculum, attitudes toward homogeneity and heterogeneity of the conditions of students in inclusive primary schools, and views of different ability in class. Questionnaire development employed each component arranged into question items in a questionnaire with two answer choices. Respondents required to choose one of the answers.

The respondents were approximately 99 parents/guardians of students who were in inclusive elementary schools in four regencies and one city in the province of Special Region of Yogyakarta. The schools, research samples, were selected using random sampling techniques by region by considering the equal distribution of locations and access to attend inclusive school training. So, it assumed that they have characteristics representing the population. The location of the school is chosen based on the distance, whether far or not from the city. Also, considering the schools which often/rarely/never attended inclusive school training held by the education agency or other institutions. (Data collection technique).

Data analysis techniques (how to scoring, categorizing, and interpreting). Data from the 
Jurnal Prima Edukasia, 7 (2), 2019 - 142

Mumpuniarti Mumpuniarti, C. Asri Budiningsih, Dinar Westri Andini, Ayu Rahayu

questionnaire were analyzed descriptively. The steps were: (1) tabulating all answer data from item questions in each component, (2) calculating the total score of each component, (3) calculating the percentage of respondents' answers from each component, and (4) providing data interpretation based on obtained percentage. Data interpretation is divided into two criteria; positive statements (if the percentage is $50 \%$ to $100 \%$ ) and negative statements (if the percentage is $0 \%$ to $50 \%$ ). A bar chart is made for each component of the parent perspective on inclusive education which used to see the comparison of data in each district/city.

\section{Result and Discussion}

Result

The results of the study are presented consecutively on each component of the perspective of parents, starting from the basics to the crucial things from the perspective of diversity, which are different abilities in the classroom. Successively presented with the number of respondents in each regency which states concretely as follows.

\section{The Phenomena of Parents View on Inclusive Understanding}

The component of understanding of inclusive from parents as respondents in Special Region of Yogyakarta are presented in Table 1. The frequency of respondents on an under- standing of inclusion is described in Figure 1. Figure 1 showed that parents still have a narrow view of inclusive. They consider that the concept of inclusive is SEN attending regular schools. The attending of SEN in regular schools is only the integration of students based on a place of learning, not to the concept of collabo-rative learning, such as different abilities in the classroom. The concept considers SEN is the responsibility of special supervisors (teacher), not shared responsibilities. This concept has not yet touched equality and justice and the concept of normalization. Here, it often assumes that SEN in a school calls as "inclusive student." Inclusive is interpret as SEN. This kind of understanding might arise labelling in school, discrimination and building a misunderstanding of the inclusive concept. Inclusive provides an open opportunity for all without considering the background of students.

Table 1. Understanding of Parent on Inclusive

\begin{tabular}{lcc}
\hline \multirow{2}{*}{\multicolumn{1}{c}{ Regency }} & \multicolumn{2}{c}{$\begin{array}{c}\text { Understanding of } \\
\text { inclusive }\end{array}$} \\
\cline { 2 - 3 } & Narrow & Correct \\
\hline Bantul Regency & 18 & 4 \\
Sleman Regency & 11 & 5 \\
Gunungkidul Regency & 16 & 6 \\
Kulon Progo Regency & 19 & 2 \\
Yogyakarta City & 11 & 7 \\
Total & 75 & 24 \\
Percentage & $75,76 \%$ & $24,24 \%$ \\
\hline
\end{tabular}

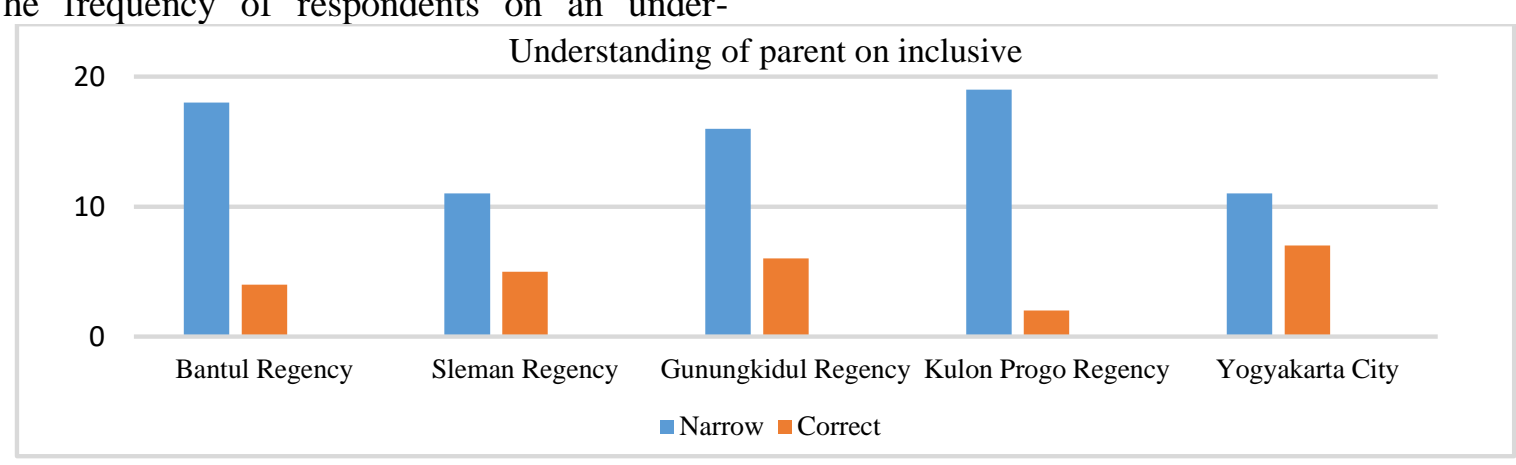

Figure 1. Understanding of parent on inclusive

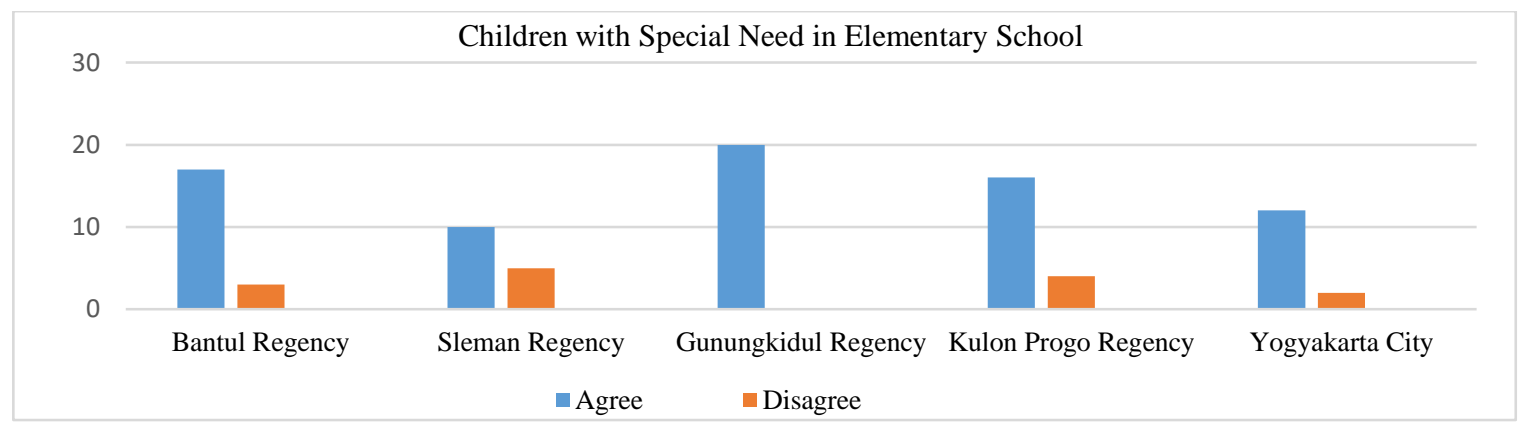

Figure 2. The Statement of parents toward SEN in school 
Jurnal Prima Edukasia, 7 (2), 2019 - 143

Mumpuniarti Mumpuniarti, C. Asri Budiningsih, Dinar Westri Andini, Ayu Rahayu

\section{The Next Phenomenon is the Statement of Parents toward SEN in Regular Schools}

Parents stated they agree and disagree with the statements with the following frequency, presented in Table 2.

Table 2. The Statement of parents toward SEN in school

\begin{tabular}{lcc}
\hline \multirow{2}{*}{ Regency } & \multicolumn{2}{c}{ SEN in regular school } \\
\cline { 2 - 3 } & Agree & Disagree \\
\hline Bantul Regency & 17 & 3 \\
Sleman Regency & 10 & 5 \\
Gunungkidul Regency & 20 & 0 \\
Kulon Progo Regency & 16 & 4 \\
Yogyakarta City & 12 & 2 \\
Total & 75 & 14 \\
Percentage & $84,30 \%$ & $15,73 \%$ \\
\hline
\end{tabular}

The phenomenon in Table 2 was then presented in Figure 2, from the respondents of five regencies in Special Region of Yogyakarta. Many parents agreed to SEN in regular schools, especially respondents from Gunungkidul Regency which almost all of them stated agree. Means, parents have already known inclusive, which is SEN in regular schools. The majority agree because inclusive education is a movement related to human rights. Human rights are something that must highly respect by all people. However, they agree it limited to the surface or acceptance that has not been followed by the correct inclusive concept. Inclusive only is limited as not to violate human rights. The concept was followed by the phenomenon of the high labelling that SEN is "inclusive children." Means, SEN is a child who still needs to be set apart, only attending a regular school. The labelling phenomenon is presented in Table 3.

The phenomena of labelling of SEN is same with Inclusive

Table 3. Labeling SEN in School

\begin{tabular}{lcc}
\hline & \multicolumn{2}{c}{ Concept of SEN } \\
\cline { 2 - 3 } \multicolumn{1}{c}{ Regencies } & $\begin{array}{c}\text { Labeling } \\
\text { SEN="anak } \\
\text { inklusif" }\end{array}$ & $\begin{array}{c}\text { No } \\
\text { Labeling } \\
\text { SEN } \\
\text { anak unik }\end{array}$ \\
\hline Bantul Regency & 10 & 9 \\
Sleman Regency & 9 & 5 \\
Gunungkidul Regency & 15 & 6 \\
Kulon Progo Regency & 17 & 4 \\
Yogyakarta City & 9 & 8 \\
Total & 60 & 32 \\
Percentage & $65,22 \%$ & $34,78 \%$ \\
\hline
\end{tabular}

The phenomenon in Table 3 was shown by the graph which marked with the concept of Special Educational Need (SEN). How SEN is referred to labelling that needs to be served specifically separately, even in regular schools. In contrast, the view that SEN is a unique child with unique special needs is not widely understood by parents. These unique needs do not need to provide separately learning, but rather learn sharing/caring and collaborative among diverse, unique needs. This also applies to all students, both with disabilities and non-disabilities. The reality today is, that parents do not have the same view as the concept. This fact is described in Figure 3 and also followed by Figure 4, which describes the view that SEN should be in special schools, not in regular schools.

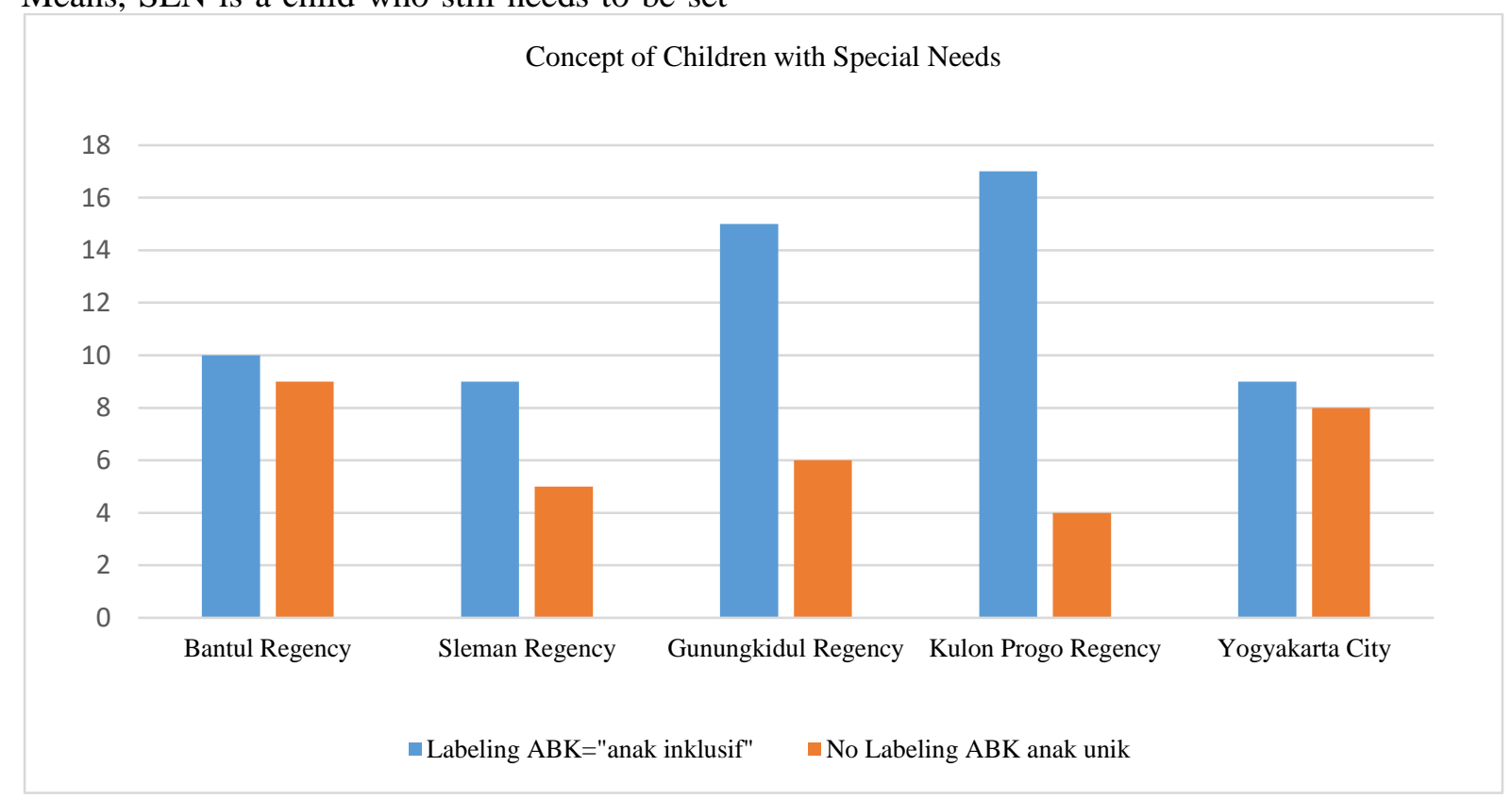


Jurnal Prima Edukasia, 7 (2), 2019 - 144

Mumpuniarti Mumpuniarti, C. Asri Budiningsih, Dinar Westri Andini, Ayu Rahayu

Figure 3. Labeling SEN in School

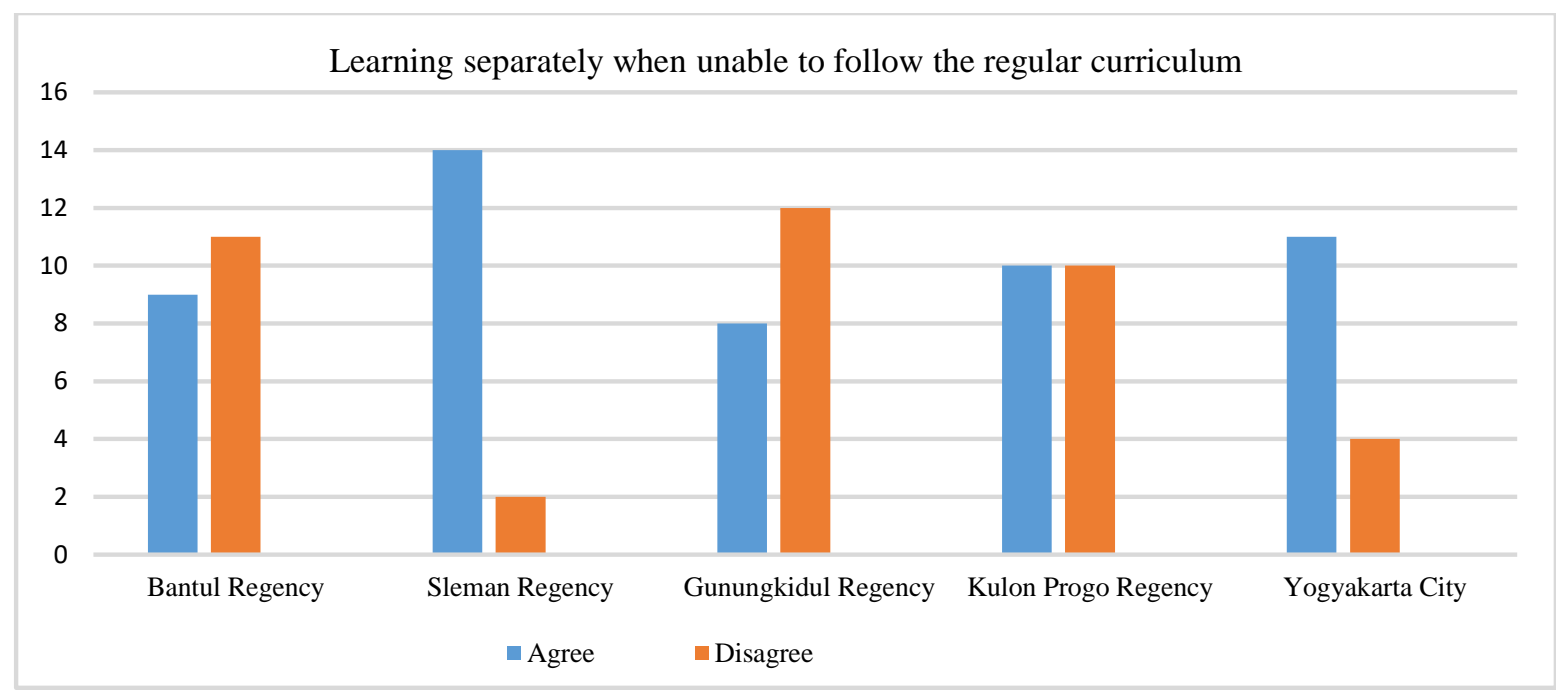

Figure 5. SEN learn separately from fellow students

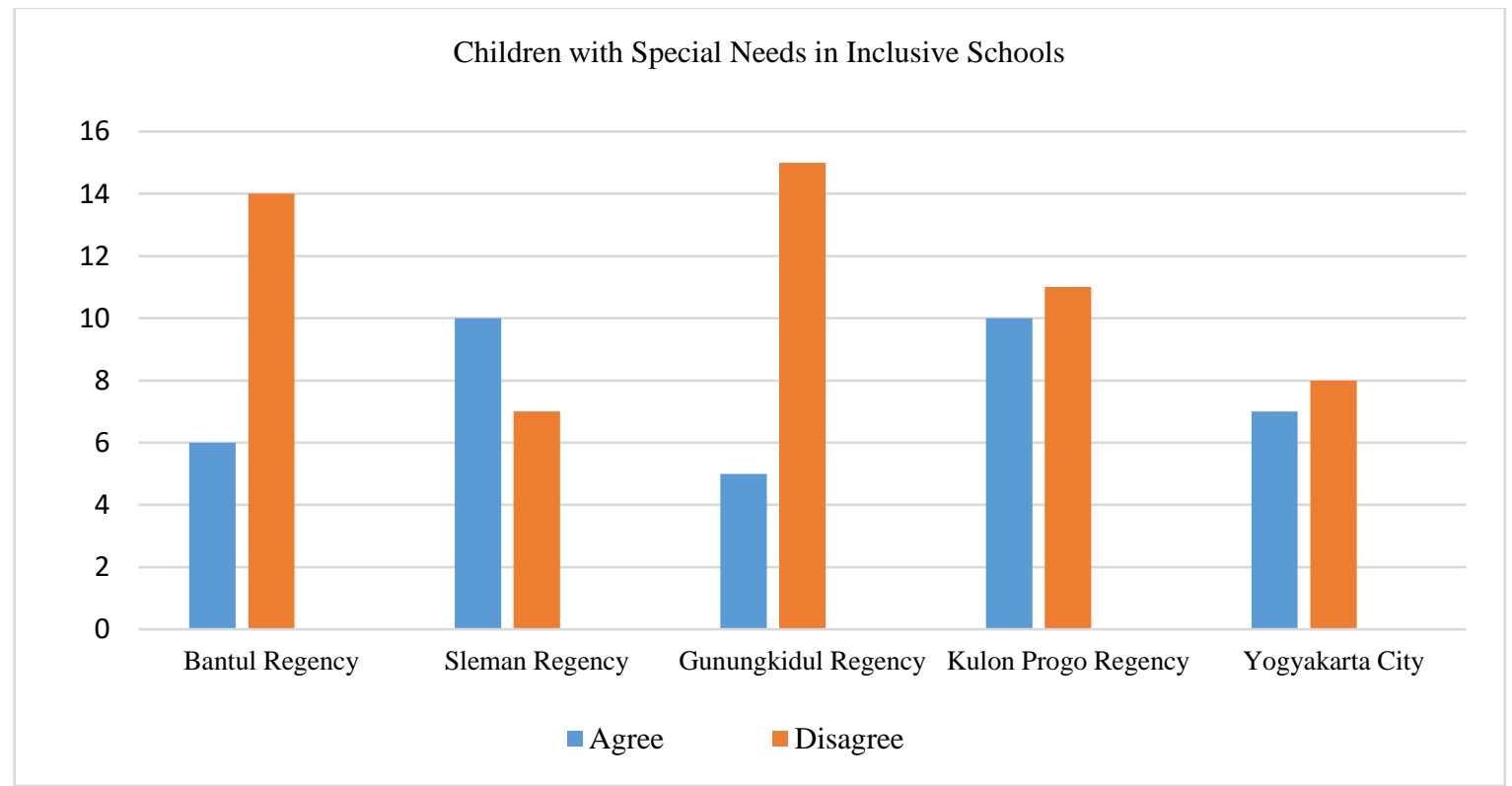

Figure 4. Students moved to SLB when they are unable to follow the regular curriculum

The data in Figure 3 showed that the concept of SEN in regular schools as inclusive children labelling is high. The label was followed by data of the phenomenon in Figure 4, which states SEN should be in special schools. The concept of labelling implies that SEN is the responsibility of special tutors. So, it is more appropriate for SEN to be in special schools. Parents' views on the correct concept of inclusive are low. And, it is followed by the fact that labelling and special needs view should be in special schools.

Phenomena of students who are unable to follow the regular curriculum move to SLB (Inclusive School)
Table 4. Students moved to SLB when they are unable to follow the regular curriculum

\begin{tabular}{lcc}
\hline & \multicolumn{2}{c}{$\begin{array}{c}\text { Students moved to SLB } \\
\text { when they are } \\
\text { Regencies }\end{array}$} \\
& $\begin{array}{c}\text { unable to follow the } \\
\text { regular curriculum }\end{array}$ \\
\cline { 2 - 3 } & Agree & Disagree \\
\hline Bantul Regency & 14 & 7 \\
Sleman Regency & 10 & 6 \\
Gunungkidul Regency & 4 & 16 \\
Kulon Progo Regency & 12 & 8 \\
Yogyakarta City & 10 & 5 \\
Total & 50 & 42 \\
\multicolumn{1}{c}{ Percentage } & $54,35 \%$ & $45,65 \%$ \\
\hline
\end{tabular}

The implication of the narrow of inclusive education view also results in high statements of 
Jurnal Prima Edukasia, 7 (2), 2019 - 145

Mumpuniarti Mumpuniarti, C. Asri Budiningsih, Dinar Westri Andini, Ayu Rahayu

the agreement if students who are unable to follow the curriculum should move to inclusive schools (SLB). However, in Gunungkidul Regency, it was more advanced with more data disagree that SEN moved to SLB. The data is presented in Table 5. And, it also described in Figure 5.

Phenomena the SEN students learn separately from fellow students

Table 5. SEN learn separately from fellow students

\begin{tabular}{lcc}
\hline \multirow{2}{*}{ Regencies } & \multicolumn{2}{c}{$\begin{array}{c}\text { Learn separately when } \\
\text { unable to follow regular } \\
\text { curriculum }\end{array}$} \\
\cline { 2 - 3 } & Agree & Disagree \\
\hline Bantul Regency & 9 & 11 \\
Sleman Regency & 14 & 2 \\
Gunungkidul Regency & 8 & 12 \\
Kulon Progo Regency & 10 & 10 \\
Yogyakarta City & 11 & 4 \\
Total & 52 & 39 \\
\multicolumn{1}{c}{ Percentage } & $57,14 \%$ & $42,86 \%$ \\
\hline
\end{tabular}

Table 5 showed data the higher score of agree, given by parents towards separate learning. And, only in Gunungkidul Regency, the opinion raised on SEN could follow the integrated learning. The disagree of the parent in Gunungkidul Regency that SEN follows the integrated learning or not separate because parents have also recognized the heterogeneous nature, shown in Table 6. So, parents in Gunungkidul Regency who are higher in recognizing student diversity and is described in Figure 6.

\section{Phenomena of Parents toward the Diversity of Students}

The data in Table 6 is a phenomenon of the diversity of parents' statements by asking information about student diversity. Means, the students who have different abilities in class need to know the diversity of potential. Also, it described in Figure 7 that parents from Gunungkidul and Kulonprogro regencies realized that students had different abilities. The awareness was followed that diverse potentials need to find out and collect the information to collect accurate data of children. The data is used as a basis for planning the learning programs for diverse students. The awareness implication of diverse student learning programs is followed by learning accommodation with curriculum adaptation. The ability of teachers in adapting the curriculum to accommodate learning needs for diverse students is urgently needed. And, it also needs support from parents. Figure 7 showed the dominated by Gunungkidul and Kulon Progo regencies in parental awareness of diversity.

Table 6. Parents toward the diversity of students

\begin{tabular}{lcc}
\hline \multirow{2}{*}{ Regencies } & \multicolumn{2}{c}{ Diversity } \\
\cline { 2 - 3 } & Heterogeneous & Homogeneous \\
\hline Bantul Regency & 7 & 13 \\
Sleman Regency & 7 & 9 \\
Gunungkidul & 20 & 0 \\
Regency & & \\
Kulonprogo & 3 & 17 \\
Regency & & \\
Yogyakarta City & 2 & 14 \\
Total & 39 & 53 \\
Percentage & $42,39 \%$ & $57,61 \%$ \\
\hline
\end{tabular}

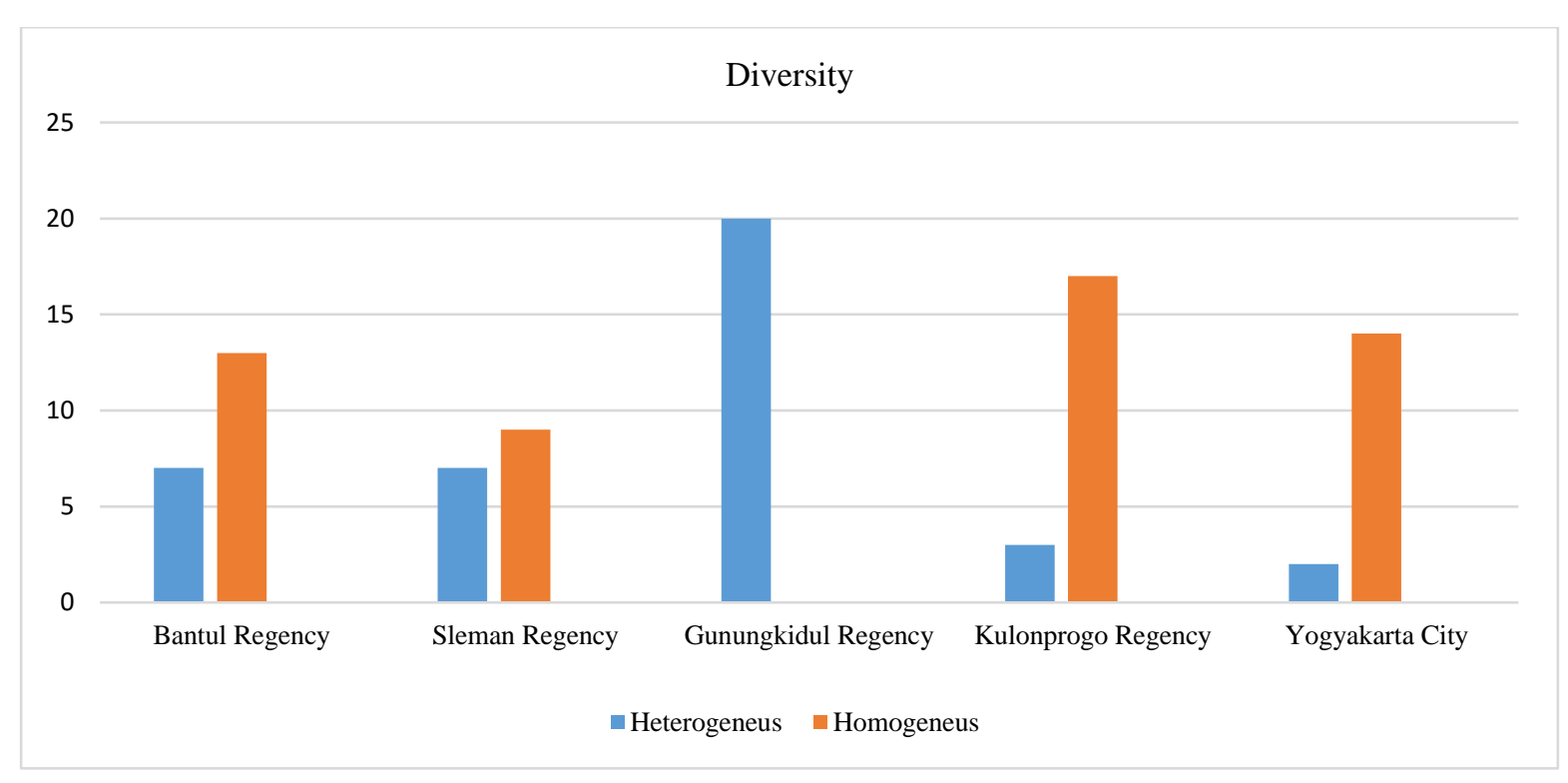

Figure 6. Parents toward the diversity of students 
Jurnal Prima Edukasia, 7 (2), 2019 - 146

Mumpuniarti Mumpuniarti, C. Asri Budiningsih, Dinar Westri Andini, Ayu Rahayu

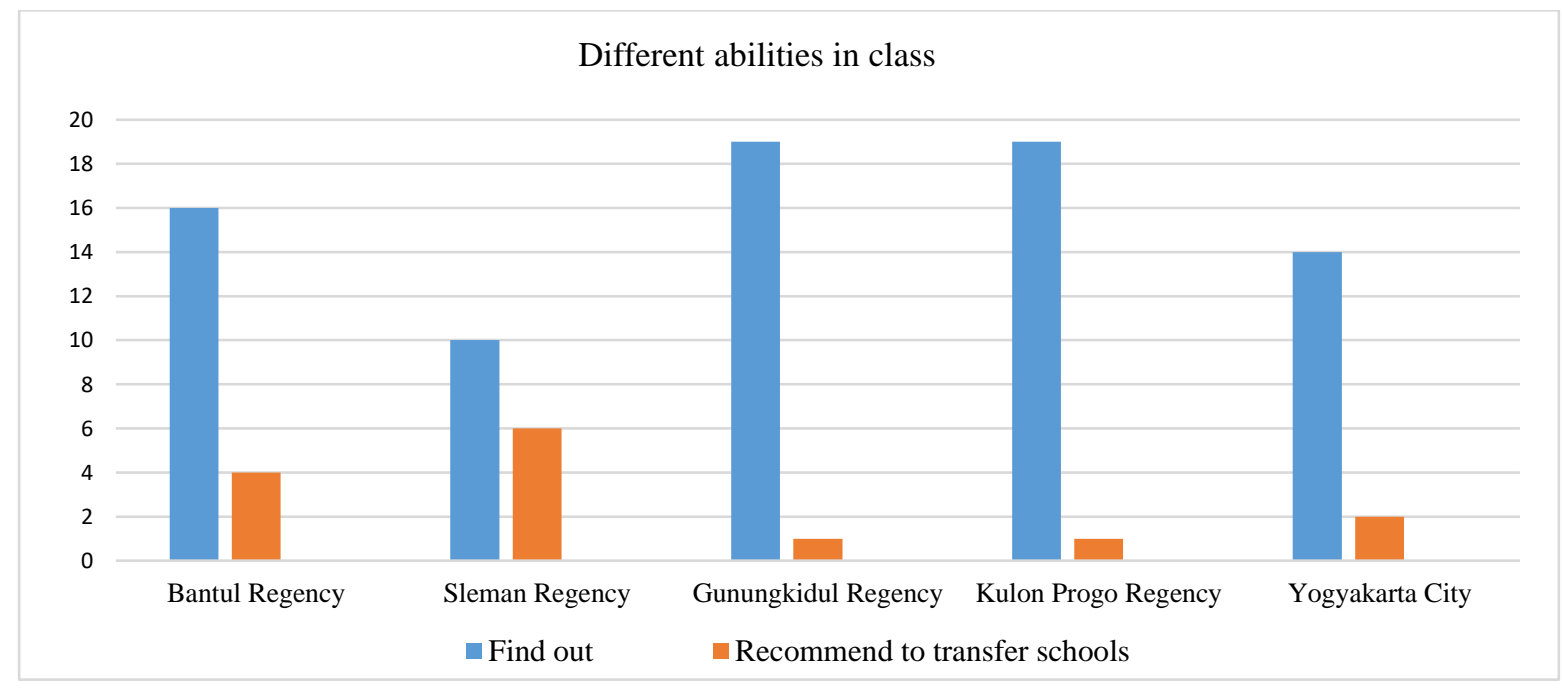

Figure 7. Teacher Assess the Different Abilities among the Class

Discussion

The changes to inclusive education need to be improved. The facts show that the review from the perspective of parents on inclusive education is only limited to the SEN in regular schools. This fact has not addressed the problem that inclusive education is accommodating diversity (Burstein et al., 2004; Conderman et al., 2017). Indirectly, it proves the labelling and discrimination in school. Whereas, the inclusive school aims to erase the discrimination, labelling and inhibit factor that all children can achieve achievement using all the potency. Each child is unique and has a different character, interest, ability, and learning need (UNESCO, 1994).

For this reason, the perspective of parents to understand inclusive education properly is much needed through education. Education, here, may through mutual discussion among policymakers in school, such as making group discussion and put this into the vision of the school, and disseminate continuously and integrating into habituation by respecting all the individual and erase the labelling. So, it will create a nice and open school atmosphere. The discussion will develop various problems, especially returning SEN exclusively to inclusive schools. The problem will not only stop at SEN in inclusive schools but will also reject human rights, equality, and justice in regular schools (Foreman, 2014).

The phenomenon of parents' attitudes to reject $A B K$ in regular schools arises along with the problem of ABK being unable to follow the curriculum in regular schools. The issue of unable to follow the curriculum becomes the reason that must be answered with the teacher's competence in curriculum adaptation (Kauffman \& Hallahan, 2011). The teacher's competency must also be accommodated by the principal to lead the teachers to improve their competence. Curriculum adaptation competence is the reason for parents to build trust in inclusive education. Furthermore, it also solves other problems when parents give a "trust." Collaboration and building trust from parents is fundamental to achieve the students' learning outcomes (Hill \& Taylor, 2004; Hoover-Dempsey et al., 2005; Hughes \& Kwok, 2007; Walker et al., 2004). Trust from parents proved that student diversity is a thing that can be collaborated harmoniously. The evidence must be presented by teachers in primary schools with curriculum adaptation competencies (Goddard et al., 2001). The role of the teacher is important, especially as the agent of change that brings changing and promotes justice to create a warm and mutual respect environment. The competence of the teacher as an agent of change needs a better understanding of the practice of learning in inclusive class (Pantić \& Florian, 2015). Thus, building motivation, teacher capacity, and maintaining the collaboration will build and solve the risk of exclusive.

Parent's perspective becomes fundamental for the problem of mutual collaboration in school achievement. They show disagree attitude when dealing with student diversity if the diversity itself might not give a benefit for learning outcomes of students (Hebel \& Persitz, 2014; Hill $\&$ Taylor, 2004). Schools, with all its components, from principals, class teachers, school administrators, parents, and special tutors, show the effort to build student achievement collaboratively. Efforts should show to parents on the 
benefits of diversity to achieve the student's achievement (Parker \& Villalpando, 2007).

Parents from two regencies; Gunungkidul and Kulon Progo regencies, regarding the issue of parents' perspective on student diversity and awareness to heterogeneous, have shown a higher positive attitude. This fact shows that both two regencies have advanced, in terms of awareness of inclusive education. Diversity and heterogeneity of students must be well known by parents with the correct perspective, because this becomes a reason contributing to problem-solving when occurs conflicts among diverse schoolmates (Riehl, 2000; Štemberger \& Kiswarday, 2018). The correct perspective is also a parameter to the development of inclusive awareness in schools. This expected perspective has been shown on two regencies in Special Region of Yogyakarta. Means, the two regencies in Special Region of Yogyakarta, are seen as more developed regencies in developing inclusive education due to the perspective of parents agree SEN in regular schools. They agreed to SEN in regular schools and realized that they would have different abilities. This attitude of agreement encourages parents to find out each other's potential so that the accommodation of potential development in learning in the classroom becomes adaptive (Hammond \& Ingalls, 2003; Hunt \& Goetz, 1997).

\section{Conclusion}

The results showed that the majority of parents still have a narrow understanding of the concept of inclusive education. So, the concept of labelling that SEN is an inclusive child is the misconception. The misconception will lead to the culture of labelling and discrimination. There is a shift of meaning inclusive. However, the majority of parents have agreed to SEN in a regular school. Besides, the understanding of separate learning is the responsibility of special tutors or, interpret as inclusive teachers. This phenomenon leads to exclusivity. Whereas, erase the exclusivity is the goal of inclusive education. Also, there is an assumption of SEN students who are unable to follow the regular curriculum, should move to inclusive school or learning separately from fellow students. And, the parent agreed to this statement.

In contrast, this fact shows untrusted from parents to school in accommodating all the diversity of students in the class. The trust must arise through evidence that a teacher can accommodate the diversity of students in the class. Two regencies in Special Region of Yogyakarta showed a higher score of positive attitudes toward heterogeneity and different abilities of students. Thus, the attitude should give persuasive education on the benefits of diversity. Understanding the benefits of diversity can be demonstrated by the teacher as education toward understanding the inclusive correctly. The concept of inclusive understanding correctly from the perspective of parents still needs to be further discussed in looking for solutions to the constraints of the development of inclusion ideally.

\section{References}

Bakar, R. (2018). The influence of professional teachers on Padang vocational school students' achievement. Kasetsart Journal of Social Sciences, 39(1), 67-72. https://doi.org/10.1016/j.kjss.2017.12.017

Burstein, N., Sears, S., Wilcoxen, A., Cabello, B., \& Spagna, M. (2004). Moving toward inclusive practices. Remedial and Special Education, 25(2), 104-116. https://doi.org/10.1177/074193250402500 20501

Christenson, S. L. (2003). The principal's role in creating inclusive schools for diverse students: A review of normative, empirical, and critical literature on the practice of educational administration. School Psychology Quarterly, 18(4), 454482.

https://doi.org/10.1521/scpq.18.4.454.269 95

Conderman, G., Liberty, L., \& DeSpain, S. (2017). Understanding accommodations, modifications, and interventions. Kappa Delta Pi Record, 53(2), 70-75. https://doi.org/10.1080/00228958.2017.12 99545

Foreman, P. (2014). Inclusion in action. Cengage Learning Australia.

Goddard, R. D., Tschannen-Moran, M., \& Hoy, W. K. (2001). A multilevel examination of the distribution and effects of teacher trust in students and parents in urban elementary schools. The Elementary School Journal, 102(1), 3-17. https://doi.org/10.1086/499690

Hallahan, D. P., \& Kauffman, J. M. (2003). Exceptional learners: Introduction to special education (9th ed.). Boston: 
Jurnal Prima Edukasia, 7 (2), 2019 - 148

Mumpuniarti Mumpuniarti, C. Asri Budiningsih, Dinar Westri Andini, Ayu Rahayu

Pearson Education.

Hammond, H., \& Ingalls, L. (2003). Teachers' attitudes toward inclusion: survey results from elementary school teachers in three southwestern rural school districts. Rural Special Education Quarterly, 22(2), 2430.

https://doi.org/10.1177/875687050302200 204

Hebel, O., \& Persitz, S. (2014). Parental involvement in the individual educational program for israeli students with disabilities. International Journal of Special Education, 29(3), 1-11.

Hill, N. E., \& Taylor, L. C. (2004). Parental school involvement and children's academic achievement. Current Directions in Psychological Science, 13(4), 161-164. https://doi.org/10.1111/j.0963-

7214.2004.00298.x

Hoover-Dempsey, K. V., Battiato, A. C., Walker, J. M. T., Reed, R. P., DeJong, J. M., \& Jones, K. P. (2001). Parental involvement in homework. Educational Psychologist, 36(3), 195-209. https://doi.org/10.1207/S15326985EP360 3_5

Hoover-Dempsey, K. V., Walker, J. M. T., Sandler, H. M., Whetsel, D., Green, C. L., Wilkins, A. S., \& Closson, K. (2005). Why do parents become involved? Research findings and implications. The Elementary School Journal, 106(2), 105-130. https://doi.org/10.1086/499194

Hughes, J., \& Kwok, O. (2007). Influence of student-teacher and parent-teacher relationships on lower achieving readers' engagement and achievement in the primary grades. Journal of Educational Psychology, 99(1), 39-51. https://doi.org/10.1037/0022-

0663.99.1.39

Hunt, P., \& Goetz, L. (1997). Research on inclusive educational programs, practices, and outcomes for students with severe disabilities. The Journal of Special Education, 31(1), 3-29. https://doi.org/10.1177/002246699703100 102

Kantavong, P., Sujarwanto, Rerkjaree, S., \& Budiyanto. (2017). A comparative study of teacher's opinions relating to inclusive classrooms in Indonesia and Thailand. Kasetsart Journal of Social Sciences, 38(3), 291-296. https://doi.org/10.1016/j.kjss.2016.05.005

Kauffman, J. M., \& Hallahan, D. P. (2011). Handbook of special education. Routledge.

Kavale, K. A., \& Forness, S. R. (2000). History, rhetoric, and reality: Analysis of the inclusion debate. Remedial and Special Education, 21(5), 279-296. https://doi.org/10.1177/074193250002100 505

Komsi, D. N., Hambali, I., \& Ramli, M. (2018). Kontribusi pola asuh orang tua demokratis, kontrol diri, konsep diri terhadap motivasi belajar siswa. Psychology, Evaluation, and Technology in Educational Research, 1(1), 55. https://doi.org/10.33292/petier.v1i1.21

LaRocque, M., Kleiman, I., \& Darling, S. M. (2011). Parental involvement: The missing link in school achievement. Preventing School Failure: Alternative Education for Children and Youth, 55(3), 115-122. https://doi.org/10.1080/104598809034728 76

Parker, L., \& Villalpando, O. (2007). A race(cialized) perspective on education leadership: Critical race theory in educational administration. Educational Administration Quarterly, 43(5), 519-524. https://doi.org/10.1177/0013161X073077 95

Parsons, J., \& Taylor, L. (2011). Improving student engagement. Current Issues in Education, 14(1). Retrieved from https://cie.asu.edu/ojs/index.php/cieatasu/ article/view/745

Paseka, A., Schwab, S., \& Paseka, A. (2019). Parents, attitudes towards inclusive education and their perceptions of inclusive teaching practices and resources perceptions of inclusive teaching practices and resources. European Journal of Special Needs Education, O0(00), 1-19. https://doi.org/10.1080/08856257.2019.16 65232

Riehl, C. J. (2000). The principal's role in creating inclusive schools for diverse students: A review of normative, empirical, and critical literature on the practice of educational administration. Review of Educational Research, 70(1), 
Jurnal Prima Edukasia, 7 (2), 2019 - 149

Mumpuniarti Mumpuniarti, C. Asri Budiningsih, Dinar Westri Andini, Ayu Rahayu

$55-81$.

https://doi.org/10.3102/003465430700010 55

Salend, S. J., \& Garrick Duhaney, L. M. (1999). The impact of inclusion on students with and without disabilities and their educators. Remedial and Special Education, 20(2), 114-126. https://doi.org/10.1177/074193259902000 209

Štemberger, T., \& Kiswarday, V. R. (2018). Attitude towards inclusive education: the perspective of Slovenian preschool and primary school teachers. European Journal of Special Needs Education, 33(1), 47-58.

https://doi.org/10.1080/08856257.2017.12 97573

The Salamanca Statement and Framework for Action on Special Needs Education. (2014). Salamanca: UNESCO \& Ministry Of Education And Science, Spain.

UNESCO. (1994). the Salamanca Statement
Framework. Policy, (June), 7-10. https://doi.org/E D -94/WS/ 18

Walker, J. M. T., Hoover-Dempsey, K. V., Whetsel, D. R., \& Green, C. L. (2004). Parental involvement in homework. Harvard Family Research Project, 1520(March 2015), 37-41. https://doi.org/10.1207/S15326985EP360 3

Wang, M. C., Haertel, G. D., \& Walberg, H. J. (1993). Toward a knowledge base for school learning. Review of Educational Research, 63(3), 249-294. https://doi.org/10.3102/003465430630032 49

Wertheim, C., \& Leyser, Y. (2002). Efficacy beliefs, background variables, and differentiated instruction of Israeli prospective teachers. The Journal of Educational Research, 96(1), 54-63. https://doi.org/10.1080/002206702095987 91 